Науковий вісник Чернівецького університету імені Юрія Федьковича: Історія. - № 2. - 2020.- С. 26-34

History Journal of Yuriy Fedkovych Chernivtsi National University. - № 2. - 2020. - pp. 26-34

DOI https: /doi.org/10.31861/hj2020.52.26-34

hj.chnu.edu.ua

УДК 94(4/9)[(470+571): 560] «1740/1780»

(С) Анатолій Ткачук* (Луцьк)

\title{
КРИМСЬКИЙ ЧИННИК В ТУРЕЦЬКО-РОСІЙСЬКИХ ВІДНОСИНАХ СЕРЕДИНИ XVIII Ст.
}

У статті проаналізовано основні причини та характер турецько-російського протистояння через оцінку геополітичних пріоритетів обох держав, у сфері яких «кримське питання» було чи не найголовнішим. Основна увага приділена аналізу головних чинників ескалаиії конфлікту напередодні анексії Криму Росією. Звернено увагу також на зіткнення геополітичних інтересів Османської імперії, Росії та Кримського ханства в Кавказькому регіоні на тлі турещько-російського антагонізму в Північному Причорномор '

Автор наголошує, щуо навіть після анексії Кримського ханства Росією, після укладення Кючук-Кайнарджсийського та Ясського мирного договорів геополітична боротьба двох імперій за гегемонію у східноєвропейському та євразійському просторі не припинилася.

Ключові слова: анексія, Кримське ханство, Османська імперія, «південне питання», Північне Причорномор'я, Російська імперія, російсько-турецька війна.

\section{CRIMEA FACTOR IN TURKISH-RUSSIAN RELATIONS IN THE MIDDLE OF THE 18th CENTURY}

Abstract. The main object of analysis of this article is the geopolitical situation in the Northern Black Sea region in the middle of the 18th century, which was primarily determined by the Turkish-Russian confrontation caused by the struggle for complete control of these strategic territories. The Ottoman Empire's gradual loss of control over its Black Sea possessions, on the one hand, and the Russian Empire's forced advance to the south, on the other, led to a conflict of interest between the two states in the region. That is why the confrontation between Turkey and Russia has largely determined the geopolitical processes on the Eurasian frontier since the mid-seventeenth century. The escalation of the Turkish-Russian conflict intensified in the middle of the 18th century when the "Crimean question» became the cornerstone of relations between the Ottoman and Russian empires. A significant event in this confrontation was the annexation of the Crimean Khanate by the Russian Empire in 1783, which ushered in a radically new stage in the development of the entire Black Sea region. Given the permanence of the Russian-Turkish confrontation in the Black Sea region and Crimea's place in it, St. Petersburg's priority was to accelerate the transformation of these territories into a Russian Black Sea bridgehead, including for the Caucasian campaign, which intensified in the late 18th century.

Therefore, another important aspect of this problem was the conflict of geopolitical interests of the Ottoman Empire, Russia and the Crimean Khanate in the Caucasus region against the background of Turkish-Russian antagonism in the Northern Black Sea. The study substantiates why in the middle of the 18th century was a sharp escalation of the Turkish-Russian confrontation and that were its main consequences for changing the geopolitical situation in the region. As for the Crimean Khanate itself, in the middle of

* к.і.н., доцент кафедри всесвітньої історії та філософії Волинського національного університету імені Лесі Українки.

PhD in History, Associate Professor, Department of World History and Philosophy, Lesya Ukrainka Volyn National University.

orcid.org/0000-0001-5219-8571

e-mail: atkachuk.vnu@gmail.com 
the 18th century in fact, it no longer played an independent role. Now, its future no longer depended on the Crimean Tatar elite, but on foreign policy trends determined by the policies of Istanbul and St. Petersburg. Subsequent events related to the conclusion and content of Kuchuk-Kainarji and Jassy treaties between Turkey and Russia were largely due to the events of the mid-18th century.

Keywords: annexation, geopolitical processes, Crimean Khanate, Ottoman Empire, "southern question», Northern Black Sea Coast, North Caucasus, Russian Empire, Russian-Turkish war.

Постановка наукової проблеми та іїі значення. Протистояння Туреччини та Росії привертає особливу увагу дослідників, оскільки воно значною мірою визначало геополітичні процеси в євразійському порубіжжі, починаючи з середини XVII ст. Активне посилення ескалації турецько-російсько конфлікту припадає на середину XVIII ст., коли наріжним каменем у взаємовідносинах Османської та Російської імперій стало «кримське питання». Знаковою подією в цьому протистоянні була анексія Кримського ханства Російською імперією 1783 р., яка започаткувала кардинально новий етап розвитку всього Чорноморського регіону.

Мета пропонованої статті полягає в аналізі головних чинників та внутрішніх механізмів процесу ескалації турецького-російського протистояння. в ході якого Кримське ханство остаточно стало об'єктом реалізації чужих геополітичних інтересів.

Аналіз досліджень із цієї проблеми засвідчує, що вона була й залишається широким полем для наукових пошуків. Серед тих праць, у яких об'єктом вивчення були турецько-російські відносини XVII-XVIII ст., $є$ робота російського історика XIX ст. Ф. Бруна ${ }^{1}$, в якій міститься аналіз внутрішньополітичної ситуації в Криму середини XVIII ст. й простежується іï вплив на політику правлячих кіл Османської та Російської імперій. Російсько-турецьким стосункам початку XVIII ст. присвячено дослідження С. Орєшкової${ }^{2}$. Проблему турецько-російського протистояння на Кавказі та його впливу на міжнародні відносини в означений для дослідження період порушує М. Маркова ${ }^{3}$. Історію Османської та Російської імперій як продовжувачів візантійського і золотоординського спадку висвітлює у своєму дослідженні А. Кадирбаєв ${ }^{4}$. Своєрідним підходом до оцінки російсько-турецьких відносин через аналіз внутрішньополітичної ситуації в Криму вирізняються роботи В. Возгріна /В. Крисаченка ${ }^{6}$, Ф. Лашкова ${ }^{7}$. Відповіді на актуальні питання історії Криму та процесів, які передували його анексії, містяться в колективній праці відомих українських істориків і сходознавців, яка була підготовлена Інститутом історії України НАН України ${ }^{8}$. Однак багато аспектів цієї проблеми сьогодні потребують нових оцінок та інтерпретацій.

Виклад основного матеріалу. Туреччина та Росія формувалися і розвивалися в близькому географічному сусідстві й в їхній історії можна знайти чимало спільного. Після нищівної поразки від Тимура в 1402 р. османи на чолі з Баязидом I, оговтавшись, продовжили приєднання нових земель і вже до кінця XV ст. вийшли за межі своїх етнічних кордонів. Схожі процеси відбувалися і в Північно-Східній Русі, де після завершення об'єднавчого процесу на початку XVI ст. постала Московія. Її правителі одразу стали на шлях зовнішньої експансії та створення євразійської держави. Територія Московії розширювалася переважно на Схід, насамперед на терени проживання етнічно, релігійно та лінгвістично близьких до турків-османів тюркських народів, які сповідували іслам. Уже в другій половині XVI ст. державність Казанського, Астраханського і Сибірського ханств було ліквідовано, а їхню територію анексовано. Османи, в свою чергу, захоплюючи Арабський Схід і Закавказзя, головний удар спрямовували все ж на Захід, поглинаючи землі, де жили християнські, переважно слов'янські народи, які сповідували православ'я. Болгарські царства, Сербське та Боснійське королівства не змогли протистояти турецькій агресії. Так приблизно в одному часовому просторі створювалися дві великі євразійські імперії, наближаючи одна до одної кордони своїх володінь'.

Міждержавні відносини між Османською імперією та Московією були встановлені в 1492 р. Проте спільних кордонів ці держави на той час ще не мали. Навіть перше турецько-російсько військове зіткнення не було пов'язане з якими-небудь взаємними територіальними претензіями. Першим збройним конфліктом можна вважати воєнні дії в районі Астрахані 1569 р. Однак вони були розпочаті турецькою стороною не заради того, аби змінити співвідношення сил у Східній Європі чи одержати якусь частину золотоординського спадку, а лише для забезпечення зручного 
шляху кримським і північнобалканським військам до театру воєнних дій, які велися проти Ірану. Після цього більше 100 років Османська імперія не проявляла жодного інтересу до цього регіону. Турецький васал, Кримське ханство, яке відало від імені османських властей проблемами північного прикордоння, почало здійснювати систематичні набіги на землі Речі Посполитої та Московського царства. Набіги ці були дуже болючими для місцевого населення, оскільки татари часто досить глибоко проникали на територію цих держав. Однак все ж це були лише набіги, походи за здобиччю і полоненими. Якихось серйозних територіальних претензій на землі Московії у другій половині XVI - першій половині XVII ст. ні татари, ні їхні османські сюзерени не висували. Утвердившись в Криму, османи на інший ординський спадок не претендували, і північно-східний напрям на той час не входив до сфери їхніх головних зовнішньополітичних інтересів.

Інтереси Московської держави до середини XVII ст. були зосереджені в основному в західному i східному напрямках. Південне прикордоння цікавило московський уряд загалом лише у зв'язку 3 необхідністю забезпечити оборону своїх володінь від кримських набігів ${ }^{10}$.

Війна Туреччини з Московією 1672-1681рр. загалом не сприймалася з ентузіазмом з обох сторін. Вона завершилася Бахчисарайським перемир'ям, яке вперше офіційно зафіксувало спільний кордон між Московською державою та Османською імперією, що проходив в основному по Дніпру, залишаючи землі між Дніпром і Бугом незаселеними.

У Росії наприкінці XVII ст., незважаючи на досить тривалу війну, були надії, що подальші відносини з Османською імперією можуть складатися мирно, що «можна 3 султаном турським мир надійний чинити» ${ }^{11}$.

Захоплення Азова (1696) відкривало для Росії перспективи утвердження в Азово-Чорноморському басейні. Молодий російський цар Петро I захопився ідеєю виходу його держави до Чорного моря і можливістю створення в його акваторії російського морського флоту. Він бажав продовження війни і завоювання Керчі. Однак Прутська невдача московського царя, повернення туркам Азова i ліквідація російської азовської флотилії відновили в регіоні попередню геополітичну рівновагу. У 1720 р. між двома державами був підписаний «Вічний мир».

Територіальні претензії до Османської імперії і заяви про необхідність взагалі знищити цю державу з вуст офіційних осіб уперше прозвучали в Росії за правління Анни Іванівни. В результаті війни 1735-1739 рр. до російських володінь було включено лише Азов, а весь османо-російський прикордонний район проголошений нейтральним і демілітаризованим ${ }^{12}$.

Після невигідного для Росії Белградського миру 1739 р. вона перейшла від воєнних акцій до економічних, дипломатичних і дестабілізаційних методів вирішення кримської та причорноморської проблеми. Однак у другій половині 40-х - 50-х pp. XVIII ст. найбільш актуальними зовнішньополітичними завданнями було втримання завойованих Петром I територій Прибалтики і мінімізація загроз інтересам Росії у Східній Європі, які виникали з боку Пруссії. Тому чорноморська проблема відійшла для Російської імперії на другий план. Проте це зовсім не означає, що вона була забута ${ }^{13}$.

Середина та друга половина XVIII ст. були складним періодом в історії Османської імперії. В першу чергу це було пов'язано із занепадом військово-ленної системи - основи господарського, політичного, військового життя держави. До середини XVIII ст. ускладнилися внутрішньополітичні проблеми, пов'язані з активізацією національно-визвольних рухів на грецьких, сербських, болгарських, албанських і інших територіях, захоплених турками. Похитнулась відносна єдність Османської держави, яка склалася в ході успішних завоювань. Загальна криза Османської імперії відбилася на боєздатності армії. Занепад військово-ленної системи зайшов так далеко, що на війну з Росією в 1768-1774 рр. вдалося зібрати ледь четверту частину сипахів з їхніми загонами. Яничари до того часу з високопрофесійного війська перетворилися загалом у зброю придворних угрупувань. Вони втратили своє бойове значення і використовувались зазвичай для каральних операцій. Відставав від європейського рівня й османський флот. Деякі спроби реорганізації армії, що здійснювалися в 40-х pp. XVIII ст., значного успіху не мали ${ }^{14}$.

У зовнішній політиці Стамбула пріоритетними напрямами стало суперництво з Персією на Кавказі та в Малій Азії, яке, втім, не доходило до широкомасштабних військових зіткнень. Звертає на себе увагу той факт, що кримський хан Арслан-Гірей, який правив у 1748-1756 pр., одержав подяку від турецького султана за дотримання умов дружби і приязні з Російською державою. Зви- 
чайно, набіги кримських татар не припинялися, проте вони вже не мали систематичного характеру і організовувалися в основному окремими князями власними силами. Варто зазначити, що такі ж набіги на кримські землі здійснювали запорозькі і донські козаки, а також підвладні Росії калмики. Постійна загроза набігів була причиною того, що обширні території, які належали Запорозькій Січі, дуже повільно заселялися. Османські ж і кримські землі, що прилягали до російських і українських земель, також фактично були своєрідною смугою відчуження. Так, території Придністров'я та Херсонщини практично не були заселеними. Землі, які лежали між Бугом і Дністром, взагалі не освоювались Туреччиною і адміністративно навіть не входили до іï складу. П. Румянцев у 1765 p. зазначав, що «турки і татари... на цих степах ніяких поселень не заводять» ${ }^{15}$.

За таких обставин російська сторона значно активізувала підривну роботу для посилення етнічних протиріч всередині ханства. В силу ряду причин об'єктивного (розбіжності в культурі, мові, способі життя і господарстві) та суб'єктивного (значна економічна залежність від Росії, постійне зіткнення з російськими підданими, складні взаємовідносини з жителями Криму) характеру, ногайські татари, які становили приблизно $40 \%$ населення Кримського ханства і займали майже всю його територію за межами півострова, більше схилялися до дотримання добросусідських відносин з Росією, ніж кримські татари. Саме ці протиріччя досить успішно почали використовувати російські агенти. Так, у 1753 р. Едисанські мурзи Канай і Шинкуша направили до Петербурга свого посланця Хаджия Акай-Кутлу з проханням про прийняття їх із всім народом в підданство російської корони, заявляючи, що головні Буджацькі мурзи з ними погоджуються (Едисанська і Буджацька орди були найсильнішими в ногайців). У 1758 р. подібні спроби було повторено. Проте російський уряд, аналізуючи зміст листів від ногайських мурз, резюмував, що «зміст їхніх листів такий, нібито ногайські правителі і едисанські та буджацькі мурзи шукали тут лише тимчасового прихистку через політику Крим-Гірей хана, а нам потрібно значно більше» ${ }^{16}$. Крім того, Росії, яка на той час була учасницею Семилітньої війни, було невигідним загострення відносин із все ще могутньою і впливовою Османською імперією. Тому справу відклали до кращих часів. Офіційно російський уряд погодився прийняти у підданство лише окремі ногайські клани.

Дещо іншою була політика стосовно кавказьких народів. Підданими Кримського хана в той час на Кавказі були адиги, які займали лівобережжя Кубані. Проте залежність останніх від Криму була номінальною. Кавказці без особливого захопленням визнавали верховенство хана і намагалися проводити самостійну політику. Звичайно, така політика адигів провокувала постійні набіги на них кримських і кубанських татар. У результаті цього не один раз різні адигські племена заявляли про своє бажання перейти в російське підданство.

Традиційно кримські хани вважали своїми підданими і кабардинців. Відповідно до Белградського договору 1739 р., Кабарда визнавалася незалежною, «буферною» територією. Але всупереч положенням цього договору, кримські хани продовжували втручатися у внутрішні справи Кабарди, вимагаючи від неї сплати данини. В 1750 р. із Петербурга на адресу турецького уряду був направлений офіційний протест у зв'язку із постійним втручанням кубанського сераскира в кабардинські справи. Та і сама Блискуча Порта у 50-х pp. XVIII ст. засилала агентів у Кабарду та Дагестан, які повинні були переконати місцевих правителів прийняти турецьке підданство і виступити проти Росії. Важливо наголосити, що й Російська імперія активно втручалася у справи Кабарди. На початку 50-х рр. туди були відіслані майори І. Барковський і П. Татаров із загонами у 400 солдатів. Окрім своєї головної місії щодо примирення ворогуючих угрупувань знаті, ці російські емісари уважно вивчали Кабарду як один із важливих театрів воєнних дій у випадку війни з Туреччиною чи Іраном. Такі заходи російського уряду однозначно сприймалися в Туреччині і Кримському ханстві як втручання у внутрішні справи Кабарди. Тому коли в 1753 р. російським емісарам вдалося на деякий час примирити місцеві ворогуючі угрупування, то Османська імперія офіційно звинуватила Росію у втручанні в справи Кабарди і в проведенні агітації з метою схилити кабардинців до вступу в російське підданство. Отже, в 50-х роках XVIII ст. йшло вперте суперництво між Росією, з одного боку, і Османською імперією та Кримським ханством - з іншого за гегемонію в Північному Причорномор'ї та на Кавказі. Лише постійний перебіг малих і великих європейських війн у 1740-1750 pр. відкладав подальші спроби Росії вирішити ті завдання, які вона ставила перед собою в ході війни $1735-1739$ pp. $^{17}$. 
Розуміючи це і враховуючи досвід попереднього збройного конфлікту, Османська імперія розпочала підготовку сприятливої для себе зовнішньополітичної ситуації перед початком нового зіткнення з Росією. 3 кінця 1750-х рр. у Стамбулі активізувалися антиросійські настрої. Враховуючи, що традиційними суперниками Османської імперії були Іран, Австрія, італійські держави, а в ході Семилітньої війни 1756-1763 pр. союзником Росії виступила і Франція, Османська імперія розпочала переговори про союз із Пруссією. Договір між двома державами був підписаний у 1761 р. Але вихід Росії із війни з Пруссією після сходження на престол Петра III і укладення російсько-прусського союзного договору зруйнували плани Стамбула.

Схожою була ситуація і в Кримському ханстві. У 1758 р. до влади в Бахчисараї в результаті повстання прийшов новий хан - Крим-Гірей. Від самого початку правління його політика набула неприхованого антиросійського спрямування. В 1758-1759 рр. новий хан активізував свою політику в Кабарді, намагаючись безуспішно схилити іiі князів до виступу проти Росії. Зазнавши невдачі, кримський хан не заспокоївся. В рамках укладеного османо-прусського договору в Бахчисараї велися переговори між ханом і представником прусського короля про конкретні воєнні акції кримських татар проти Росії та Австрії. Крим-Гірей готовий був виставити 16-тисячний корпус татарської іррегулярної кінноти. Проте вихід Росії з війни з Пруссією перекреслив плани спільних прусськотурецьких дій. Пропоновані Пруссією диверсії проти австрійських військ на території Угорщини для Крим-Гірея були не особливо цікавими.

Невдачі кримського правителя спонукали турецького султана в 1764 р. прийняти рішення про усунення Крим-Гірея від влади. Тим більше, що його ризикована і агресивна зовнішня політика поєднувалася з неврівноваженістю і у внутрішніх справах, за що йому дали прізвисько «Делі-хан» («Божевільний хан»). Про це свідчать як османські, так і російські джерела. Але все ж основною причиною усунення хана була його агресивна політика, яка б неминуче привела ханство, а слідом за ним і Османську імперію, до війни з Росією і союзною з нею імперією Габсбургів. За тих зовнішньополітичних умов така війна аж ніяк не входила до планів Стамбула. Хоча ворожість та агресивність Крим-Гірея до Росії була цілком зрозумілою, враховуючи зіткнення інтересів Бахчисарая і Санкт-Петербурга на прикордонних територіях, а також те, що російський консул у Криму О. Никифоров, діючи відповідно до спеціальної інструкції Колегії іноземних справ, займався на півострові ще й розвідницькою діяльністю. Не випадково наступник Крим-Гірея на ханському престолі - Селім-Гірей III у першу чергу висунув вимогу видворити Никифорова з Криму.

Таким чином, політика причорноморських держав у середині XVIII ст. лише нагнітала напругу в регіоні та призводила до поглиблення взаємних протиріч. При цьому основна причина формування передумов нового воєнного турецько-російсько конфлікту полягала в тому, що Белградський мир 1739 р. не вирішив ключових проблем у регіоні. Відповідно до його результатів, Росія не могла досягнути здійснення своїх геополітичних і економічних завдань. Османській імперії, зі свого боку, не вдалося встановити гегемонію на Кавказі і зберегти в Північному Причорномор'ї відносно комфортне для себе становище, яке склалося після невдалого Прутського походу російської армії 1711 р. Кримське ханство, в свою чергу, не лише не забезпечило собі геополітичної та економічної вигоди - воно взагалі втратило статус самостійної сторони конфлікту і, з усією очевидністю, перетворилося із суб'єкта політичного процесу в його об'єкт.

Є підстави стверджувати, що в планах Петербурга відразу після завершення війни з Пруссією у 1763 р. була підготовка до війни з Османською імперією за Північне Причорномор'я та Північний Кавказ. А за тих умов це могло означати лише одне - прагнення зруйнувати існуючу на той час систему військово-політичної та релігійно-ідеологічної залежності Кримського ханства від Османської імперії. Не випадково майже відразу після сходження на російський престол Катерини II їй було представлено відому доповідь канцлера М. Воронцова «Про Малу Татарію». У своїй доповіді канцлер вказав, що сусідство кримських татар «для Росії набагато шкідливіше, ніж Порти Оттоманської; вони є схильними до грабунків і злодійств, майстерні в швидких і неочікуваних військових нападах, а до останньої з турками війни завдавали Росії відчутної шкоди й образи частими набігами, захопленням у полон багатьох тисяч жителів... Росія змушена для захисту і безпеки своєї утримувати проти них оборонні лінії із великою чисельністю війська і перебувати, ніби під час війни, у стані бойової готовності». У зв'язку з цим Воронцов робив висновки, що «півострів Крим 
місцезнаходженням своїм настільки важливий, що дійсно може вважатися ключем до російських і турецьких володінь; до того часу, поки він залишається в турецькому підданстві, він завжди буде небезпечним для Росії, і навпаки, коли б він перебував під владою Російської держави, чи не був би залежним від когось, то не лише безпека для Росії надійно була б утверджена, але тоді були б Азовське і Чорне моря під іï владою» ${ }^{18}$. На основі цього свідчення можна стверджувати, що російський уряд на початку 1760-х рр. цілком усвідомлював неминучість у найближчий час нового військового зіткнення з Османською імперією.

Досить активними були дії Росії і на Кавказі. Навесні 1763 р. в урочищі Моздок розпочалося будівництво однойменної фортеці. Вона стала ключовою у Кизлярсько-Моздокській лінії укріплень, яка в той час створювалася. Завдяки своєму розміщенню ця фортеця, по-перше, повністю контролювала найбагатші пасовища князів Великої Кабарди, а, по-друге, за словами Крим-Гірея, нова фортеця розташовувалася на такому місці, яке «є єдиним вільним для проїзду і сполучення дагестанців з кубанцями і кримцями». Якщо вона буде добудована до кінця, то «будь-яке сполучення у татар з дагестанцями зовсім буде перерване». Фортецю добудували в 1765 р., розмістивши в ній потужний гарнізон, на озброєнні якого було 40 гармат.

У той же час і Османська імперія посилювала укріплення та гарнізони своїх північнопричорноморських і кавказьких оборонних ліній. В 1761 р. між Стамбулом і Берліном був укладений союзний договір, спрямований проти Росії та Австрії. Крім того, кримський хан у 1759 р. перевів частину ногайців із Буджака на лівий берег Дніпра і поселив їх між річками Білозеркою та Рогачиком, що було заборонено Белградським договором. Користуючись тим, що будівництво Моздока викликало незадоволення кабардинських князів, Крим-Гірей у листопаді 1763 р. запевнив їх, що «якщо вони 3 російською стороною мають зв'язок через поселення в урочищі Моздок, то він, хан, обіцяє не допустити їх до цього силою» ${ }^{19}$.

Це послугувало підставою для звернення ряду князів Великої Кабарди наприкінці 1764 р. до кримського хана 3 проханням зруйнувати Моздокську фортецю, незважаючи на те, що вона була побудована на території Російської імперії. В червні 1765 р. кубанський сераскир здійснив воєнну акцію в районі Кизляра, однак вона виявилася безрезультатною.

Отже, обидві сторони готувалися до війни, яка ставала неминучою. Погляди істориків на назріваючий конфлікт різняться між собою. Так, зокрема, В. Возгрін вважає, що Османська імперія і Кримське ханство стали жертвою неспровокованої агресії з боку Росії, яка знищила самобутню цивілізацію, що склалася на півострові ${ }^{20}$. А. Фішер робить висновок, що поряд з економічними причинами постійного тиску Росії на Крим був досить сильним елемент своєрідної помсти з боку росіян за багато століть кримської агресії ${ }^{21}$. Значна частина істориків схильна вважати багаторічну боротьбу Росії з Туреччиною за Північне Причорномор'я такою, що була зумовлена захистом південних рубежів і потребами економічного розвитку країни.

Згідно з домінуючою в сучасній російській історіографії думкою, саме в Північному Причорномор'ї найбільш інтенсивно в той період відбувався процес розширення Російської імперії до своїх «природних» геополітичних кордонів. Такими нібито для неї на півдні були Чорноморське узбережжя, Великий Кавказ, Каспійське море та напівпустелі Середньої Азії. Відповідно до цієї концепції, нормальний розвиток держави чи етносу неможливо уявити без опори на ці природні кордони. Якщо етнос не доріс до них, то він відчуває нестачу необхідних для розвитку ресурсів. Якщо етнос переріс ці кордони, то він відчуває значну напругу через переорієнтацію відповідних цьому економічних і торгових зв'язків, а також через необхідність захисту периферійних для себе територій. Тому боротьба за вихід до Балтійського і Чорного морів продовжувалася тривалий час. Вона повинна була закінчитися перемогою Росії, оскільки ця перемога мала вирішальне значення для російської державності, яка від самого свого становлення розвивалася на грунті імперської ідеї. Така позиція не є новою - схожі погляди обстоював ще в XIX ст. відомий російський дипломат, публіцист і мислитель А. Жоміні, найближчий соратник канцлера А. Горчакова. Він зазначав, що зовнішня політика Катерини II багато в чому визначалася саме геополітичним становищем Росії. «Задихаючись у своїх територіальних межах між Швецією, Польщею, татарами й турками, Росії було необхідно розширити і досягнути своїх природних кордонів і моря. Це право будь-якої держави. Всі держави були утворені в силу цього закону. Росія повинна була вчинити так само» ${ }^{22}$. Отож, основ- 
ною причиною протистояння Росії і Туреччини було об'єктивне прагнення першої до розширення своїх кордонів, а другої - недопущення відторгнення своїх периферійних територій, які опинилися у сфері геополітичних інтересів Росії. Кримське ханство (як і Кабарда, Осетія, Молдавія, Валахія та інші землі) виявилося об'єктами у чужій геополітичній грі. Уже з часу приєднання до Росії Східної України Кримське ханство могло або залишатися в орбіті інтересів Османської імперії, або потрапити до сфери інтересів Російської імперії. Іншої альтернативи у нього не було.

Катерина II, яка прийшла до влади у 1762 р., вірогідно, спробувала б відразу переорієнтувати зовнішню політику Росії на традиційний союз з Віденським двором і тим самим розпочати війну 3 Османською імперією та Кримським ханством. Але цьому завадило польське питання, яке постало на порядку денному тодішньої російської зовнішньої політики. У боротьбі навколо вибору кандидата на польський престол союзником Росії стала Пруссія, а союзник Росії з «південного питання» - Австрія виявилася в даному випадку іiі ворогом. Цілком зрозуміло, що за таких умов вирішення «південного питання» знову відкладалося на невизначений термін, який, проте, настав уже в 7090-х роках XVIII ст.

Висновки. Отже, ескалація турецько-російського конфлікту не випадково припала саме на середину XVIII ст. Є всі підстави вважати, що причини російсько-турецького антагонізму в названий період лежали, перш за все, у невирішеності проблеми Причорноморського і Кавказького регіонів, які з початку XVIII ст. перетворилися фактично в зони проникнення та освоєння для обох держав. Стамбул повинен був вирішити для себе проблему Причорноморського і Кавказького регіонів, а разом з тим - одержати важелі впливу в Речі Посполитій як ключовій державі для протидії прямим антиосманським крокам як з боку Росії, так і з боку імперії Габсбургів. Російська імперія також за будь-яку ціну прагнула розширити свою територію, здобути вихід до Чорного моря та одержати можливість контролювати Кримський півострів. Що стосується самого Кримського ханства, то на середину XVIII ст. воно самостійної ролі фактично вже не відігравало. Вектор майбутніх змін тепер залежав більшою мірою не від кримськотатарської еліти, а від зовнішньополітичних тенденцій, які визначили політику Стамбула та Петербурга. Однак навіть після анексії Кримського ханства Росією, після укладення Кючук-Кайнарджийського та Ясського мирного договорів геополітична боротьба двох імперій за гегемонію у східноєвропейському та євразійському просторі не припинилася.

1 Ф.К. Брун, Крым в половине ХVIII столетия [Crimea in the middle of the 18th century], Одесса, Тип. Л. Нитче, $1867,128 \mathrm{c.}$

2 С.Ф. Орешкова, Русско-турецкие отношения в начале XVIII в. [Russian-Turkish relations at the beginning of the XVIII century], Москва, Наука, 1971, 206 c.

3 О.П. Маркова, Россия, Закавказье и международные отномения в XVIII веке [Russia, Transcaucasia and international relations in the 18th century], Москва, Наука, 1966, 323 с.

4 А.Ш. Кадырбаев, Османская и Российская империи: общее византийское и золотоордынское насле$\partial u$ [Ottoman and Russian empires: common Byzantine and Golden Horde heritage], Восток, 2003, №2, с. 138-145.

5 В.Е. Возгрин, Исторические судьбы крымских татар [Historical destinies of the Crimean Tatars], Moсква, Аграф, 1992, 288 с.

6 В. Крисаченко, Історія Криму. Кримське ханство [History of Crimea. Crimean Khanate], Київ, Твім інтер, 2000, 335 c.

7 Ф. Лашков, Шагин-Гирей, последний крымский хан: Истор. очерк [Shagin-Girey, the last Crimean khan: Istor. feature article], Киевская старина, 1886, №9, с. 37-80.

8 Крим: шлях крізь віки. Історія у запитаннях і відповідях [Crimea: the way through the ages. History in questions and answers], НАН України. Інститут історії України, відп. ред. В.А. Смолій, Київ, Ін-т історії України НАН України, 2014, 456 с.

9 А.Ш. Кадырбаев, Османская и Российская империи: общее византийское и золотоордынское наслеdue, с. 145.

10 С.Ф. Орешкова, Русско-турецкие отношения в начале XVIII в., с. 34.

11 Письмо Петра I князю Федору Юрьевичу Ромодановский от 31 мая 1696 г. Письма и бумаги императора Петра Великого. Том 1 (1688-1701) [Letter from Peter I to Prince Fyodor Yuryevich Romodanovsky 
dated May 31, 1696. Letters and papers from Emperor Peter the Great. Volume 1 (1688-1701)], Санкт-Петербург, Издатель: «Государственная типография», 1877, с. 27.

12 С.Ф. Орешкова, Русско-туреикие отношения в начале XVIII в., с. 39.

13 Р.Т. Дейников, Россия, Туриия и Крымское ханство в 40-60-х годах XVIII века [Russia, Turkey and the Crimean Khanate in the 40s-60s of the 18th century], Русская история, 2009, №6, с. 148.

14 А.Д. Новичев, История Туричии [History of Turkey], Санкт-Петербург, Полигон АСТ, 1963, с. 223.

15 Письмо П. А. Румянцева генерал-майору Е. А. Щербинину о защите южной пограничной линии. От 1 октября 1765 г. [P. A. Rumyantsev's letter to Major General E. A. Shcherbinin on the protection of the southern border line. October 1, 1765], П.А. Румянцев: Сборник документов и материалов, под ред. П.К. Фортунатова, Москва, Военное издательство, 1953, Т. 2, 1768-1775, с. 6.

16 Постановление русского правительства об отношениях с Крымским ханством от 8 ноября 1758 г. [Decree of the Russian government on relations with the Crimean Khanate of November 8, 1758], А.А. Новосельский, Документы по истории России XVIII в., Москва, Издательство АН СССР, 1957, с. 611.

17 О.П. Маркова, Россия, Закавказье и международные отношения в XVIII веке, с. 178.

18 Доклад канилера М.И. Воронизова «О Малой Татарии» от 9 ноября 1762 года [Report of Chancellor M. I. Vorontsov «On Little Tartary» dated November 9, 1762], А.А. Новосельский, Документы по истории России XVIII века, с. 150.

19 М.В. Масаев, Присоединение Крыма к России [Accession of Crimea to Russia], Симферополь, Таврида, 1997, c. $115-116$.

20 В.Е. Возгрин, Исторические судьбы крыммких татар, с. 278.

21 A. Fisher The Russian Annexation of the Crimea 1772-1783, Cambridge: Cambridge University Press, 2008, 200 p.

22 Из рукописи А.Г. Жомини о внешней политике Екатеринь II [From the manuscript of AG Jomini on the foreign policy of Catherine II], предисл. П.В. Стегния, О.Ю. Волковой, Новая и новейшая история, 1999, № 2 , c. 78 .

\section{References}

1. F.K. Brun, Krыm v polovyne XVIII stoletyia [Crimea in the middle of the 18th century], Odessa, Typ. L. Nytche, $1867,128 \mathrm{~s}$.

2. S.F. Oreshkova, Russko-turetskye otnoshenyia v nachale XVIII v. [Russian-Turkish relations at the beginning of the XVIII century], Moskva, Nauka, 1971, 206 s.

3. O.P. Markova, Rossyia, Zakavkaze y mezhdunarodnыe otnoshenyia v XVIII veke [Russia, Transcaucasia and international relations in the 18th century], Moskva, Nauka, 1966, $323 \mathrm{~s}$.

4. A.Sh. Kadurbaev, Osmanskaia y Rossyiskaia ymperyy: obshchee vyzantyiskoe y zolotoordыnskoe nasledye [Ottoman and Russian empires: common Byzantine and Golden Horde heritage], Vostok, 2003, №2, c. 138-145.

5. V.E. Vozghryn, Ystorycheskye sudbы krыmskykh tatar [Historical destinies of the Crimean Tatars], Moskva, Ahraf, 1992, $288 \mathrm{~s}$.

6. V. Krysachenko, Istoriia Krymu. Krymske khanstvo [History of Crimea. Crimean Khanate], Kyiv, Tvim inter, 2000, 335 s.

7. F. Lashkov, Shahyn-Hyrei, poslednyi krыmskyi khan: Ystor. ocherk [Shagin-Girey, the last Crimean khan: Istor. feature article], Kyevskaia staryna, 1886, №9, s. 37-80.

8. Krym: shliakh kriz viky. Istoriia u zapytanniakh i vidpovidiakh [Crimea: the way through the ages. History in questions and answers], NAN Ukrainy. Instytut istorii Ukrainy, vidp. red. V. A. Smolii, Kyiv, In-t istorii Ukrainy NAN Ukrainy, 2014, 456 s.

9. A.Sh. Kadыrbaev, Osmanskaia y Rossyiskaia ymperyy: obshchee vyzantyiskoe y zolotoordbnskoe nasledye, s. 145.

10. S.F. Oreshkova, Russko-turetskye otnoshenyia v nachale XVIII v., s. 34.

11. Pysmo Petra I kniaziu Fedoru Yurevychu Romodanovskyi ot 31 maia 1696 h. Pysma y bumahy ymperatora Petra Velykoho. Tom 1 (1688-1701) [Letter from Peter I to Prince Fyodor Yuryevich Romodanovsky dated May 31, 1696. Letters and papers from Emperor Peter the Great. Volume 1 (1688-1701)], Sakt-Peterburh, Yzdatel: «Hosudarstvennaia typohrafyia», 1877, s. 27.

12. S.F. Oreshkova, Russko-turetskye otnoshenyia v nachale XVIII v., s. 39.

13. R.T. Deinykov, Rossyia, Turtsyia y Kromskoe khanstvo v 40-60-kh hodakh KhVIII veka [Russia, Turkey and the Crimean Khanate in the 40s - 60s of the 18th century], Russkaia ystoryia, 2009, №6, c. 148. 
14. A.D. Novychev, Ystoryia Turtsyy [History of Turkey], Sankt-Peterburh, Polyhon AST, 1963, s. 223.

15. Pysmo P. A. Rumiantseva heneral-maioru E. A. Shcherbynynu o zashchyte yuzhnoi pohranychnoi lynyy. Ot 1 oktiabria 1765 h. [P. A. Rumyantsev's letter to Major General E.A. Shcherbinin on the protection of the southern border line. October 1, 1765], P.A. Rumiantsev: Sbornyk dokumentov y materyalov, pod red. P.K. Fortunatova, Moskva, Voennoe yzdatelstvo, 1953, T. 2, 1768-1775, s. 6.

16. Postanovlenye russkoho pravytelstva ob otnoshenyiakh s Krыmskym khanstvom ot 8 noiabria $1758 \mathrm{~h}$. [Decree of the Russian government on relations with the Crimean Khanate of November 8, 1758], A.A. Novoselskyi, Dokumentы po ystoryy Rossyy XVIII v., Moskva, Yzdatelstvo AN SSSR, 1957, s. 611.

17. O.P. Markova, Rossyia, Zakavkaze y mezhdunarodnыe otnoshenyia v XVIII veke, s. 178.

18. Doklad kantslera M.Y. Vorontsova «O Maloi Tataryy» ot 9 noiabria 1762 hoda [Report of Chancellor M. I. Vorontsov «On Little Tartary» dated November 9, 1762], A.A. Novoselskyi, Dokumentb po ystoryy Rossyy XVIII veka, s. 150.

19. M.V. Masaev, Prysoedynenye Krыma k Rossyy [Accession of Crimea to Russia], Symferopol, Tavryda, 1997, s. $115-116$.

20. V.E. Vozghryn, Ystorycheskye sudbы krыmskykh tatar, c. 278.

21. A. Fisher The Russian Annexation of the Crimea 1772-1783, Cambridge: Cambridge University Press, 2008, $200 \mathrm{p}$.

22. Yz rukopysy A. H. Zhomyny o vneshnei polytyke Ekaterynd II [From the manuscript of AG Jomini on the foreign policy of Catherine II], predysl. P.V. Stehnyia, O.Iu. Volkovoi, Novaia y noveishaia ystoryia, 1999, № 2, s. 78 . 